\title{
PERSEPSI CIVITAS AKADEMIKA TERHADAP KESETARAAN GENDER DAN KEPEMIMPINAN PEREMPUAN DI IAIN PADANGSIDIMPUAN
}

\author{
Eka Sustri Harida \\ Lecturer of English Education Program on Tarbiyah and Paedagogy Faculty at State for \\ Islamic Studies (IAIN) Padangsidimpuan \\ email: esha_stainpasid@yahoo.com
}

\begin{abstract}
This research was based on misconception or misunderstanding on the concept of gender and the less acceptance on the female's leadership in State Institute for Islamic Studies (IAIN) Padangsidimpuan. The aims of this research are to describe the perception of civitas academic on gender equality and on women's leadership in IAIN Padangsidimpuan. The method has been used in this research was qualitiative research by using observation, questionnairesm and interviews. The informants of this research was 48 students and 40 persons from lecturers and others. Data were analyzed through grouping, verifying, interpreting, and taking conclusion. The result of this studying shown that all civitas acedemics IAIN Padangsidimpuan was known enough about the gender equality and also felt welcome to the female leader. From $100 \%$ of informants of this research, $75,34 \%$ civitas academics knew about or familiar with the equality of gender and also $78,60 \%$ welcome to the female leadership. Thus, it can be stated that the concepts of gender equality was understood enough and being applied in IAIN Padangsidimpuan, it was proved by appreciating and accepting the leadership from women in IAIN Padangsidimpuan.
\end{abstract}

Key Words:

\begin{abstract}
Abstrak
Penelitian ini berangkat dari pemikiran bahwa masih ada ketidak mengertian tentang konsep gender dan ketidak mengertian terhadap kepemimpinan perempuan oleh civitas akademika IAIN Padangsidimpuan. Tujuan penelitian ini untuk menjaring sejauh mana persepsi civitas akademika IAIN Padangsidimpuan terhadap kesetaraan gender dan kepemimpinan perempuan di lingkungan IAIN Padangsidimpuan. Metode yang digunakan dalam menjawab pertanyaan penelitian adalah melalui pendekatan kualitatif, dengan menggunakan instrumen observasi, angket, dan wawancara. Adapun informan yang menjadi sumber penelitian ini adalah civitas akademika IAIN Padangsidimpuan yang terdiri dari 48 orang Mahasiswa serta 40 orang dari unsur Dosen dan Pegawai. Data analisis melalui proses pengelompokan, verifikasi, interpretasi, dan menyimpulkan. Hasil penelitian menunjukkan bahwa civitas akademika IAIN Padangsidimpuan cukup memahami tentang kesetaraan gender maupun penerimaan terhadap kepemimpinan perempuan, artinya civitas akademika IAIN Padangsidimpuan cukup memahami dengan baik tentang konsep gender dan menerima kesetaraan gender $(75,34 \%)$, begitu pula dengan kepemimpinan perempuan $(78,60 \%)$. Dengan demikian dapat dikatakan bahwa konsep kesetaraan gender sudah cukup difahami dengan baik, serta kesetaraan gender sudah dilaksanakan di IAIN Padangsidimpuan; hal itu terbukti dengan cukup diterimanya kepemimpinan perempuan di IAIN Padangsidimpuan.
\end{abstract}

Kata Kunci: Persepsi, Civitas Academic, Kesetaraan Gender, Kepemimpinan Perempuan 


\section{PENDAHULUAN}

Perempuan adalah makhluk Allah yang diciptakan setara dengan makhluk lainnya, juga memiliki peranan penting dalam memajukan bangsa dan negara; karena dari perempuan-perempuan baiklah terlahir generasi yang baik. Peningkatan perempuan dalam pembangunan bukanlah isu yang baru, dari zaman dahulu sudah didengar bahwa Raden Ajeng Kartini adalah pelopor untuk memperjuangkan kondisi kaum perempuan melalui emansipasi wanita. Dalam pemerintahan isu tentang peningkatan pemberdayaan perempuan diangkat dengan gencar pada tahun 2000-an dalam agenda dan prioritas pembangunan nasional. Hal tersebut termaktub dalam Agenda Permasalahan dan Pembangunan Nasional tahun 2004 - 2009¹.

Pembangunan nasional memiliki 3 (tiga) agenda pembangunan nasional tahun 20042009 berupa: 1) menciptakan Indonesia yang aman dan damai; 2) Mewujudkan Indonesia yang adil dan demokratis; dan 3) Meningkatkan kesejahteraan rakyat Indonesia ${ }^{2}$. Dalam rangka mencapai agenda yang kedua (mewujudkan Indonesia yang adil dan demokratis), pemerintah telah menyusun 5 skala prioritas. Salah satu skala prioritas tersebut menyangkut kepada kesetaraan gender: terjaminnya keadilan gender bagi peningkatan peran perempuan dalam berbagai bidang pembangunan yang tercemin dalam berbagai perundangan, program pembangunan, dan kebijakan publik; membaiknya angka GDI (Gender-related Development Index) dan angka GEM (Gender Empowerment Measurement); dan menurunnya tindak kekerasan terhadap perempuan dan anak; serta meningkatnya kesejahteraan dan perlindungan anak ${ }^{3}$.

Untuk mencapai sasaran tersebut, prioritas diberikan kepada peningkatan kualitas kehidupan dan peran perempuan serta kesejahteraan dan perlindungan anak dengan kebijakan yang diarahkan untuk:

(1) memajukan tingkat keterlibatan perempuan dalam proses politik dan jabatan publik; (2) meningkatkan taraf pendidikan dan layanan kesehatan serta programprogram lain untuk mempertinggi kualitas hidup dan sumber daya kaum perempuan; (3) meningkatkan kampanye anti kekerasan terhadap perempuan dan anak-anak; (4) menyempurnakan perangkat hukum pidana yang lebih lengkap dalam melindungi setiap individu dari kekerasan dalam rumah tangga; (5) meningkatkan kesejahteraan dan perlindungan anak; serta (6) memperkuat kelembagaan dan jaringan pengarusutamaan gender dan anak, termasuk ketersediaan data dan peningkatan partisipasi masyarakat ${ }^{4}$.

\footnotetext{
${ }^{1}$ Agenda Pembangunan Nasional diakses dari http://www.bappenas.go.id/files/7113/5230/0985/ bab-3pengembangan-kebudayaan-yang-berlandaskan-pada-nilai-nilai-luhur.pdf pada Mei 2014.

${ }^{2}$ Ibid. hlm.12

${ }^{3}$ Ibid. hlm. 13.

${ }^{4}$ Ibid. hlm. 14.
} 
Dengan demikian dapat disimpulkan bahwa pemberdayaan perempuan merupakan hal yang mutlak untuk dilakukan dalam rangka meningkatkan pembangunan nasional. Selain itu juga dalam rangka meningkatkan partisipasi perempuan dalam segala bidang sehingga pemberdayaan terhadap kaum perempuan dapat terwujud dengan baik.

Lingkungan kampus Institut Agama Islam Negeri (IAIN) Padangsidimpuan tidak terlepas dari isu gender dan kepemimpinan. Apalagi saat ini perempuan juga ikut andil dalam kesuksesan dan kemajuan kampus ini. Tentunya hal ini perlu menjadi perhatian bersama. Secara sekilas diduga bahwa saat ini masih adanya kesenjangan terhadap konsep gender dan kesetaraan gender. Selain itu peneliti juga menduga bahwa masih ada penolakan terhadap kepemimpinan perempuan oleh masyarakat. Tiak tertutup kemungkinan bahwa di kampus tercinta ini hal tersebut juga terjadi. Bertolak dari dugaan tersebut kiranya perlu diadakan suatu penelitian yang berkaitan dengan pemahaman konsep kesetaran gender. Bilamana hal itu terbukti maka perlu dilakukan langkah-langkah sosialisasi tentang konsep gender, kesetaran gender dan kebijakan pengarusutamaan gender di Paangsidimpuan khususnya di kampus Institut Agama Islam Negeri (IAIN) Padangsidimpuan.

Adapun tujuan dari penelitian ini adalah untuk mengungkapkan bagaimana pemahaman civitas akademika terhadap perempuan berkarir serta terhadap kepemimpinan perempuan di lingkungan IAIN Padangsidimpuan.

Penelitian ini terkait dengan Persepsi Perempuan Berkarir dan Masyarakat Kampus tentang Kesetaraan Gender dan Kepemimpinan Perempuan di IAIN Padangsidimpuan. Dalam hal ini akan dibahas hal yang terkait dengan persepsi, konsep gender, kesetaraan gender, pengarusutamaan gender, peran perempuan dalam pembangunan dan kepemimpinan perempuan.

Persepsi

Persepsi merupakan hasil fikiran terhadap sesuatu. Persepdi dalam bahasa Inggris "Perception" berarti "a way of seeing or understanding something" 5 . Menurut Sarlito Wirawan (1983 : 94) alam Sofiyati persepsi sebagai merupakan a) suatu proses berfikir, b) proses pengambilan keputusan c) penafsiran terhadap obyek dan d) hasil dari stimulus ${ }^{6}$. Jadi dikatakan bahwa persepsi merupakan suatu proses penginderaan, stimulus yang diterima oleh individu melalui alat indera yang kemudian diinterpretasikan sehingga individu dapat memahami dan mengerti tentang stimulus yang diterimanya tersebut. Proses menginterpretasikan stimulus ini biasanya dipengaruhi pula oleh pengalaman dan proses belajar individu. Faktor yang mempengaruhi persepsi ada dua; faktor internal dan eksternal. ${ }^{7}$ Kemudian Thoha (1993) ${ }^{8}$ berpendapat bahwa persepsi pada umumnya terjadi karena dua faktor, yaitu faktor internal dan faktor eksternal.

\footnotetext{
${ }^{5}$ Martin H. Manser. Oxford Learners' Pocket Dictionary. Oxford University Press. hlm. 305

${ }^{6}$ Sofi Sufiarti. Persepsi Perempuan Berkarir Di Lingkungan UPI Tentang Konsep Kesetaraan Gender. Laporan Penelitian. hlm. 6.

${ }^{7}$ Ibid.
} 
Dengan demikian dapat disimpulkan bahwa persepsi merupakan fikiran seseorang terhadap sesuatu berdasarkan stimulus dengan dipengaruhi oleh faktor-faktor seperti yang telah dijelaskan di atas.

\section{Konsep Gender}

Kata gender dalam bahasa Indonesia dipinjam dari bahasa Inggris secara harfiah "gender" berarti jenis kelamin, sama halnya dengan seks yang juga jenis kelamin. Untuk memahami konsep gender harus dibedakan antara kata gender dengan seks. Seks mengacu pada pengertian perbedaan biologis jenis kelamin yang merupakan kodrat Tuhan karenanya bersifat permanen serta tidak dapat dipertukarkan. Sementara pengertian gender adalah sebagai berikut:

a. Gender mengacu pada perbedaan jenis kelamin yang bukan bersifat biologis dan bukan kodrat Tuhan.

b. Gender adalah sifat yang melekat pada kaum laki-laki maupun perempuan yang dikonstruksikan secara sosial dan kultural.

c. Gender adalah perbedaan peran, fungsi, tanggung jawab antara laki-laki dan perempuan yang merupakan hasil konstruksi sosial dan dapat berubah sesuai dengan kemajuan zaman.

d. Gender adalah semua hal yang dapat dipertukarkan antara sifat perempuan dan laki-laki yang bisa berubah dari waktu ke waktu serta berbeda dari tempat ke tempat lainnya, maupun berbeda dari suatu kelas ke kelas lainnya.

e. Gender menunjuk pada perbedaan perilaku antara laki-laki dan perempuan yang "society constructed", jadi diciptakan oleh laki-laki dan perempuan itu sendiri melalui proses sosial budaya yang panjang. (Pelatihan kepemimpinan pengurus lembaga perempuan, 2002)9

Selanjutnya, menurut Ilmu Sosiologi dan Antropologi, gender itu sendiri adalah perilaku atau pembagian peran antara laki-laki dan perempuan yang sudah dikonstruksikan atau dibentuk di masyarakat tertentu dan pada masa waktu tertentu pula. ${ }^{10}$ Fakih juga memberikan defenisi gender sebagai "perbedaan yang bukan biologis dan bukan kodrat Tuhan". ${ }^{11}$ Perbedaan bilologis yakni perbedaan jenis kelamin atau sex yang merupakan kodrat Tuhan, sementara gender adalah perbedaan perilaku antara laki-laki dan perempuan yang dikonstruksi secara sosial, yakni perbedaan yang bukan kodrat atau bukan ketentuan dari Tuhan melainkan diciptakan oleh manusia melalui proses sosial dan budaya. Kemudian dikatakan dalam skripsi Laela yang dikutip dari Siti Musyda Mulya ${ }^{12}$ bahwa gender

${ }^{8}$ Ibid.

${ }^{9}$ Sofi Sufiyarti. Persepsi Perempuan... Hlm. 9-10.

${ }^{10}$ Fahriah Tahar, Pengaruh Diskriminasi Gender dan Pengalaman terhadap Profesionalitas Auditor. Skripsi yang tidak dipublikasikan. Makasar: universitas hasanuddin. Hlm. 15.

${ }^{11}$ Fakih, Mansour. Analisis Gender \& Transformasi Sosial. Yogyakarta: Pustaka Pelajar Offset. Hlm. 71.

${ }^{12}$ Musdah Mulia. Kepemimpinan Perempuan di Kampus. Diakses dari www.kalyanamitra. or.id/2014 /02/ kepemimpinan-perempuan-di-kampus/ pada Mei 2014. 
merupakan seperangkat sikap, tanggungjawab, peran, tugas, hak, dan perilaku yang melekat pada laki-laki dan perempuan yang dibentuk oleh lingkungan budaya dan masyarakat.

Jadi dapat disimpulkan bahwa, gender berbeda dengan sex. Sex merupakan sesuatu yang diberikan Allah yang merupakan kodrat manusia yang tetap dan tidak bisa dirubah, dianya merupakan jenis kelamin, laki-laki dan perempuan. Sedangkan gender merupakan perbedaan antara laki-laki dan perempuan berdasarkan peran, tanggungjawab, tugas, hak dan tingkah laku bukan berdasarkan jenis kelamin melainkan berdasarkan lingkungan dan budaya.

\section{Kesetaraan Gender}

Kesetaraan Gender adalah kesamaan kondisi bagi laki-laki dan perempuan untuk memperoleh kesempatan dan hak-haknya sebagai manusia, agar mampu berperan dan berpartisipasi dalam kegiatan politik, ekonomi, sosial budaya, pertahanan dan keamanan, dan kesamaan dalam menikmati hasil pembangunan ${ }^{13}$. Kesetaraan gender adalah kesetaraan kondisi bagi laki-laki dan perempuan untuk memperoleh kesempatan dan hak-haknya sebagai manusia, agar mampu berperan dan berpartisipasi dalam kegiatan politik, ekonomi, sosial budaya, pertahanan dan keamanan nasional, dan kesamaan dalam menikmati hasil pembangunan tersebut. ${ }^{14}$ Jadi kesetaraan gender adalah menerima dan menilai secara setara

1) perbedaan antara laki-laki dan perempuan;

2) perbedaan peran yang dipegang oleh laki-laki dan perempuan dalam masyarakat;

3) memahami bahwa perbedaan kondisi hidup laki-laki dan perempuan pada dasarnya karena fungsi melahirkan pada perempuan;

4) Menerima perbedaan laki-laki dan perempuan sebagai hikmah;

5) Kesetaraan gender tidak sinonim dengan persamaan;

6) Kesetaraan gender berarti sederajat dalam keberadaan, sederajat dalam keberdayaan dan keikutsertaan disemua bidang kehidupan domestik dan publik. ${ }^{15}$

Jadi dengan demikian dapat diartikan bahwa kesetaraan gender itu adalah memiliki nilai persamaan antara laki-laki dan perempuan bisa berupa kesamaan peran dan partisipasi. Kesetaraan gender merupakan kesempatan perempuan untuk memiliki hak sebagai manusia sama dengan manusia lainnya.

\section{Pengarusutamaan Gender}

Pengarusutamaan gender atau disingkat $\mathrm{PUG}^{16}$ adalah strategi yang dilakukan secara rasional dan sistimatis untuk mencapai dan mewujudkan kesetaraan dan keadilan gender

\footnotetext{
${ }^{13}$ diakses dari http://bppkbkajen.blogspot.com/2012/05/arti-dan-istilah-seputaran-pelaksanaan.html. Arti dan Istilah Seputaran Pelaksanaan Pengarusutamaan Gender, tanggal 22 Mei 2014.

${ }^{14}$ Sofi Sufiyarti. Persepsi Perempuan...

${ }^{15} \mathrm{Ibid}$.

${ }^{16}$ Diakses dari http://id.wikipedia.org/wiki/Pengarusutamaan_gender
} 
dalam sejumlah aspek kehidupan manusia (rumah tangga, masyarakat dan negara), melalui kebijakan dan program yang memperhatikan pengalaman, aspirasi, kebutuhan dan permasalahan perempuan dan laki-laki ke dalam perencanaan, pelaksanaan, pemantauan dan evaluasi dari seluruh kebijakan dan program diberbagai bidang kehidupan dan pembangunan. Selanjutnya PUG merupakan strategi yang dibangun untuk mengintegrasikan gender menjadi laki dan perempuan. ${ }^{17}$

Pengarusutamaan gender (Gender Mainstreaming) adalah suatu strategi untuk mencapai kesetaraan dan keadilan gender melalui perencanaan dan penerapan kebijakan yang berperspektif gender pada organisasi dan institusi ${ }^{18}$. Pengarusutamaan gender merupakan strategi alternatif bagi usaha pencepatan tercapainya kesetaraan gender karena nuansa kepekaan gender menjadi salah satu landasan dalam penyusunan dan perumusan strategi, struktur, dan sistem dari suatu organisasi atau institusi, serta menjadi bagian dari nafas budaya di dalamnya.

Jadi dapat disimpulkan bahwa pengarusutamaan gender adalah strategi yang dilakukan untuk mencapai kesetaraan gender dalam segala lingkup yang ada.

\section{Kepemimpinan Perempuan}

Kepemimpinan perempuan menjadi isu publik yang selalu diperbincangkan, dan telah memancing polemik dan debat antara yang pro dan kontra terhadap pemimpin perempuan dalam sebuah negara, kendatipun pengakuan atas hak dasar kemanusiaan tampak mengalami peningkatan yang signifikan diberbagai belahan dunia. Pengakuan ini juga berlaku atas hak perempuan sebagaimana yang sejajar dengan laki-laki. Stigma bahwa perempuan tidak perlu sekolah tinggi-tinggi, toh akhirnya ke dapur juga seringkali dijadikan alat untuk membenarkan tindakan tidak adil terhadap kaum perempuan. Budaya Patriarkhi mempengaruhi terbentuknya struktur dan sosial politik yang timpang di masyarakat, sehingga perempuan yang pada posisi lemah hanya bisa bertahan dalam ruang domestiknya.

Kepemimpinan perempuan adalah kepemimpinan yang dilakukan oleh perempuan. Selain menjadi orang nomor satu di lingkungan yang dipimpinnya, dia juga memiliki wewenang untuk menentukan keputusan. Sejumlah penelitian merumuskan, ciri-ciri kepemimpinan perempuan memiliki sejumlah keunikan dan berbeda dari kepemimpinan laki-laki ${ }^{19}$. Misalnya, dalam pengambilan keputusan, perempuan cenderung menggunakan gaya demokratis dan partisipatif daripada laki-laki. Perempuan dinilai lebih interpersonal dan bisa mendengarkan lebih baik sebagai keterampilan yang dapat membuat orang lain merasa nyaman dan penting. Selain itu, yang terpenting adalah perempuan memiliki

\footnotetext{
${ }^{17}$ diakses dari http://bppkbkajen.blogspot.com/2012/05/arti-dan-istilah-seputaran-pelaksanaan.html,

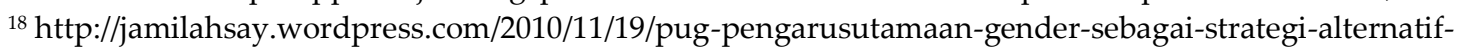
mewujudkan-kesetaraan-gender-dalam-masyarakat/

${ }^{19}$ Musdah Mulia. Kepemimpinan Perempuan di Kampus. Diakses dari www.kalyanamitra. or.id/2014 /02/ kepemimpinan-perempuan-di-kampus/ pada Mei 2014.
} 
pandangan lebih kuat pada nilai-nilai kesetaraan. Perempuan juga dapat menjadi lebih kooperatif dan mendukung, di samping tidak suka menonjolkan diri dan kompetitif. Mereka tidak suka berkonflik, relatif sabar, lebih telaten, teliti, lebih memperhatikan hal-hal kecil dan rumit, serta kolegial.

Terkait dengan kepemimpinan perempuan dalam surat At-Taubah ayat 71 juga dinyatakan bahwasanya perempuan dan laki-laki mendapatkan hak yang sama:

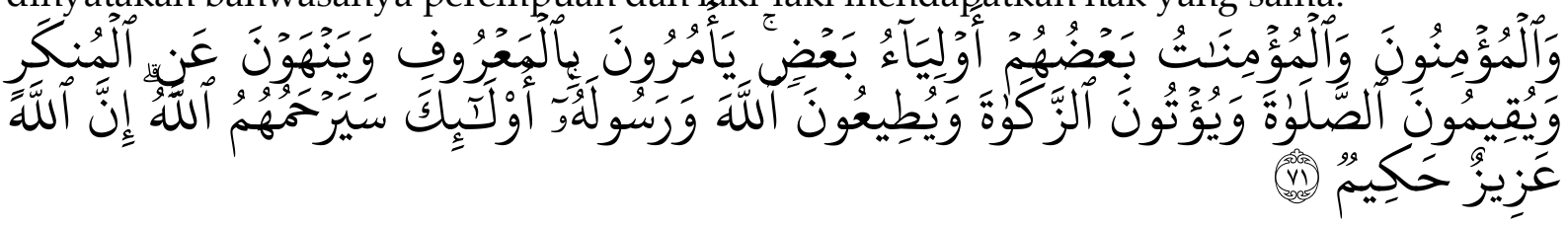

Artinya:

“Dan orang-orang yang beriman, lelaki dan perempuan, sebahagian mereka (adalah) menjadi penolong bagi sebahagian yang lain. mereka menyuruh (mengerjakan) yang ma'ruf, mencegah dari yang munkar, mendirikan shalat, menunaikan zakat dan mereka taat pada Allah dan Rasul-Nya. mereka itu akan diberi rahmat oleh Allah; Sesungguhnya Allah Maha Perkasa lagi Maha Bijaksana." 20

Ayat ini digunakan oleh Quraisy Shihab sebagai ayat yang membolehkan perempuan menjadi pemimpin.21 Dalam ayat tersebut dinyatakan bahwa laki-laki dan perempuan merupakan penolong satu sama lainnya dalam mengerjakan yang ma'ruf dan mencegah yang mungkar. Selama sama-sama mengerjakan kebaikan dan berjalan di jalan Allah, lakilaki dan perempuan dipandang sama, yang berbeda hanya tingkat keimanannya.

Bukti bahwa Islam tidak melarang kepemimpinan perempuan ada pada surat AnNaml ayat 23-24:

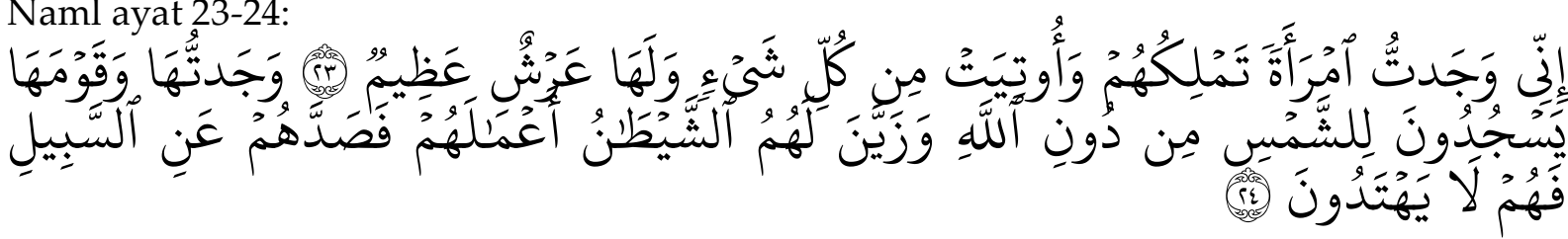

Artniya:

“Sesungguhnya Aku menjumpai seorang wanita yang memerintah mereka, dan dia dianugerahi segala sesuatu serta mempunyai singgasana yang besar. Aku mendapati dia dan kaumnya menyembah matahari, selain Allah; dan syaitan Telah menjadikan mereka memandang indah perbuatan-perbuatan mereka lalu menghalangi mereka dari jalan (Allah), sehingga mereka tidak dapat petunjuk, yaitu ratu Balqis yang memerintah kerajaan Sabaiyah di zaman nabi Sulaiman." 22

\footnotetext{
${ }^{20}$ Alqur'an Digital.

${ }^{21}$ Diakses dari https://www.academia.edu/3529945/Kepemimpinan_Perempuan_dalam_Perspektif_AlQuran_Perempuan_sebagai_Pimpinan_Publik

${ }^{22}$ Al-Qur'an Digital.
} 
Dalam ayat tersebut Allah menyetujui kepemimpinan Ratu Balqis yang memerintah kerajan Sabiyah pada zaman Nabi Sulaiman. Artinya tidak ilarang perempuan untuk menjadi seorang pemimpin, apalagi kepemimpinan yang dapat membawa kepada kemaslahatan, serta tidak melupakan kodtratnya sebagai perempuan. Quraish Shihab menyatakan bahwa kepemimpinan perempuan itu merupakan upaya perempuan dalam melakukan kepemimpinan dengan tetap memelihara harkat dan martabatnya sebagai perempuan.

Dalam hal ini peneliti akan melihat bagaimana persepsi masyarakat kampus tentang kesetaraan gender serta bagaimana pelaksanaan kepemimpinan yang dilakukan oleh perempuan, sebagai gambaran tentang efektifitas kepemimpinan perempuan, sehingga dapat dijadikan sebagai masukan dalam rangka menyusun kepemimpinan di masa mendatang.

Ada beberapa beberapa penelitian senada yang terkait dengan penelitian ini; pertama dilakukan oleh Sufi Sufiarti ${ }^{23}$ yang menemukan bahwa dalam hal memahami konsep gender perempuan lebih memahami konsep gender daripada laki-laki. Adapun pemahaman para perempuan tentang gender tidak disertai dengan pemahaman tentang kepemimpinan perempuan, karena sebahagian besar masih terpengaruh dengan budaya dominasi laki-laki.

Berikutnya penelitian yang dilakukan oleh Ika Rahmawati24 yang menemukan bahwa guru dan siswa memahami konsep gender, namun pemahaman guru lebih luas dalam rangka memahami konsep gender, sementara murid hanya memahami sebatas perbedaan antara laki-laki dan perempuan saja. Selain itu konsep kesetaraan gender ini berimplikasi pada penggunaan dan pemanfaatan sumber dan lingkungan belajar.

Selanjutnya penelitian yang dilakukan oleh Zulfikri ${ }^{25}$ yang menemukan bahwa dalam semangat al-Qur'an tidak ada jenis kelamin yang diistimewakan. Ada keistimewaan perempuan dibalik kelemahannya yang membuat perempuan bisa menjadi perempuan. Penelitian yang dilakukan oleh Imam Suraji $\mathrm{dkk}^{26}$ yang menemukan bahwa tingkat pemahaman kyai terhadap masalah gender masih tergolong seang atau cukup dan tingkat kepeulian kyai dalam membangun kesetaraan gender tergolong tinggi.

Terkait dengan temuan di atas, saat ini peneliti ingin melihat bagaimana persepsi masyarakat kampus yang terdiri dari perempuan berkarir dan laki-laki yang bekerja sebagai pegawai dan dosen di IAIN Padangsidimpuan. Dengan demikian diharapkan nanti hasil penelitian ini akan membawa pengaruh yang cukup baik bagi pelaksanaan kesetaraan gender di IAIN Padangsidimpuan.

\footnotetext{
${ }^{23}$ Fahriah Tahar, Pengaruh Diskriminasi...

${ }^{24}$ Ika Rahmawati. Pemahaman Guru dan Siswa tentang Konsep Gender dan Implikasinya dalam Aktifitas Pembelajaran Pendidikan Agama Islam di SMA Muhammadiyah 2 Yogyakarta.

${ }^{25}$ Zulfikri. Konsep Kepemimpinan

${ }^{26}$ Direktorat Perguruan Tinggi Agama Islam. Sinopsis dan Indeksasi Hasil Penelitian Kompetitif Dosen PTAIN Tahun 1999 - 2003.(Laporan Penelitian) Imam Suraji, dkk. Peran Kyai dalam Membangun Kesadaran Gender di Kota Pekalongan. Hlm.191 - 194.
} 


\section{METODE}

Penelitian ini akan dilaksanakan di STAIN Padangsidimpuan Jl. H.T. Rizal Nurdin, Sihitang Padangsidimpuan. Proses penelitian akan dilaksanakan lebih kurang 7 (tujuh) bulan, mulai dari Juni 2014 sampai dengan November 2014. Berdasarkan pendekatan analisis data, penelitian ini menggunakan pendekatan kualitatif, yaitu penelitian yang dilakukan dengan mengamati fenomena disekitarnya dan dianalisis dengan menggunakan logika ilmiah. Objek penelitiannya adalah civitas akademika IAIN Padangsidimpuan, berasal dosen baik dengan tugas tambahan maupun dosen biasa, dan pegawai; informan penelitian ini adalah 40 (empat puluh) orang dan sejumlah 48 (empat puluh delapan) orang mahasiswa yang mewakili 4 (empat) fakultas. Data diperoleh dengan angket dan wawancara serta observasi. Analisis dilakukan dengan verifikasi, pengelompokan, interpretasi dan pengambilan kesimpulan. Data dicek kebenarannya dengan menggunakan teknik trianggulasi.

\section{TEMUAN}

Civitas Akademika di lingkungan IAIN Padangsidimpuan memahami hal yang berbeda-beda terhadap kesetaraan gender ini. Berikut disampaikan hasil penelitian yang didapat dari penjaringan tentang kesetaraan gender terhadap mahasiswa adalah sebesar 70,26\%. Dari skor perolehan di atas dapat dikategorikan bahwa civitas akademika IAIN Padangsidimpuan yang dalam hal ini adalah mahasiswa cukup memahami tentang kesetaraan gender dalam kategori "cukup", yaitu 70,26\% yang berada antara 51\% - 75\%.

Kategori skor tersebut didapat berdasarkan kategorisasi sebagai berikut:

1) Persepsi yang "baik" diberi skor $76 \%$ sampai dengan $100 \%$.

2) Persepsi yang "cukup" diberi skor $51 \%$ sampai dengan $75 \%$.

3) Persepsi yang "kurang baik" diberi skor $26 \%$ sampai dengan $50 \%$.

4) Persepsi yang "tidak baik" diberi skor $0 \%$ sampai dengan $25 \%$

Sementara untuk civitas akademika dikalangan dosen dan pegawai terlihat berada pada kategori "baik" karena berada pada kategori 76\% sampai dengan 100\%, yakni 81,43\%. Hal itu trelihat dari perhitungan tentang pemahaman kesetaraan gender oleh dosen dan pegawai adalah $81,43 \%$.

Dari data tersebut, jelas bahwasanya dosen dan pegawai lebih memahami konsep kesetaraan gender daripada mahasiswa, tetapi jelas bahwa kesetaraan gender sudah cukup difahami dan disadarai oleh civitas akademika IAIN Padangsidimpuan. Pengertian dan pemahaman tentang konsep dan kesetaraan gender sudah cukup merata di IAIN Padangsidimpuan, walaupun sumber data belum seluruh civitas akademika IAIN Padangsidiampuan, namun dari gambaran yang didapat ini, peneliti meyakini bahwa 
sumber penelitian yang diambil datanya ini cukup memahami tentang bagaimana seharusnya memperlakukan gender dan meletakkan konsep gender dalam kehidupan.

Selanjutnya, dari seluruh hasil perhitungan angket yang didapat, maka pendapat masyarakat IAIN Padangsidimpuan atau civitas akademika IAIN Padangsidimpuan tentang kepemimpinan perempuan adalah sejumlah 75,34\%.

Kategori skor tersebut didapat berdasarkan kategorisasi sebagai berikut:

1) Persepsi yang "baik" diberi skor $76 \%$ sampai dengan $100 \%$.

2) Persepsi yang "cukup" diberi skor 51\% sampai dengan $75 \%$.

3) Persepsi yang "kurang baik" diberi skor $26 \%$ sampai dengan $50 \%$.

4) Persepsi yang "tidak baik" diberi skor $0 \%$ sampai dengan $25 \%$.

Artinya, secara garis besar civitas akademika IAIN Padangsidimpuan cukup memahami tentang kesetaraan gender. Dari skor yang didapat di atas dapat dikategorikan pengetahuan tentang kesetaraan gender di lingkungan IAIN Padangsidimpuan dipersepsikan oleh masyarakat kampus IAIN Padangsidimpuan masuk dalam kategori "cukup" yaitu berada antara 51\% sampai dengan 75\%.

Persentase data angket tentang kesetaraan gender yang diberikan kepada para informan penelitian dapat dilihat pada tabel di bawah ini:

Tabel 2:

Persentase Persepsi Civitas Akademika terhadap Kesetaraan Gender

\begin{tabular}{|c|c|c|c|c|c|c|c|c|c|}
\hline \multirow{2}{*}{$\begin{array}{l}\text { NO. } \\
\text { ANG- } \\
\text { KET }\end{array}$} & \multicolumn{2}{|c|}{ SETUJU } & \multicolumn{2}{|c|}{$\begin{array}{l}\text { TIDAK } \\
\text { SETUJU }\end{array}$} & \multirow{2}{*}{$\begin{array}{l}\text { NO. } \\
\text { ANG- } \\
\text { KET }\end{array}$} & \multicolumn{2}{|c|}{ SETUJU } & \multicolumn{2}{|c|}{$\begin{array}{l}\text { TIDAK } \\
\text { SETUJU }\end{array}$} \\
\hline & $\mathbf{F}$ & $\%$ & $\mathbf{F}$ & $\%$ & & $\mathbf{F}$ & $\%$ & $\mathbf{F}$ & $\%$ \\
\hline 1 & 55 & 62,5 & 32 & 36,4 & 11 & 64 & 72,7 & 21 & 23,9 \\
\hline 2 & 82 & 93,2 & 5 & 5,7 & 12 & 66 & 75 & 21 & 23,9 \\
\hline 3 & 52 & 59 & 29 & 32,9 & 13 & 67 & 76,1 & 22 & 25 \\
\hline 4 & 53 & 60,2 & 35 & 39,8 & 14 & 66 & 75 & 20 & 22,7 \\
\hline 5 & 80 & 90,9 & 5 & 5,7 & 15 & 58 & 65,9 & 29 & 32,9 \\
\hline 6 & 80 & 90,9 & 5 & 5,7 & 16 & 54 & 61,4 & 31 & 35,2 \\
\hline 7 & 12 & 13,6 & 74 & 84,1 & 17 & 19 & 21,6 & 65 & 73,9 \\
\hline 8 & 39 & 44,3 & 48 & 54,5 & 18 & 58 & 65,9 & 29 & 32,9 \\
\hline 9 & 25 & 28,4 & 61 & 69,3 & 19 & 59 & 67 & 29 & 32,9 \\
\hline 10 & 65 & 73,9 & 24 & 27,3 & 20 & 41 & 46,6 & 46 & 52,3 \\
\hline \multicolumn{6}{|c|}{ JUMLAH } & 1095 & & 631 & \\
\hline
\end{tabular}

Dari data angket di atas terlihat bahwasanya ada keragaman persepsi tentang kesetaraan gender di IAIN Padangsidimpuan, sesuai dengan penjelasan yang telah 
diberikan sebelumnya. Namun jelas dari penjelasan atau dapat yang didapat civitas akademika IAIN Padangsidimpuan cukup menerima dan memahami tentang kesetaraan gender, namun saja perlu untuk lebih diotingkatkan agar tidak ada kesenjangan dan bias gender yang terjadi sehingga mengesampingkan peranan perempuan.

Sehingga pada akhirnya, dapat diambil kesimpulan, baik dari hasil observasi, wawancara, dan angket bahwa kesetaraan dan pemahaman gender suah cukup ada pada civitas akademika IAIN Padangsidimpuan. Namun walaupun demikian agar peranan perempuan tetap menjadi suatu kekuatan perempuan haruslah tetap meningkatkan kualitas, peranan, serta kinerjanya dalam setiap kegiatan dan aktivitas di IAIN Padangsidimpuan.

Berbicara tentang yang memegang pimpinan di IAIN PaDangsidimpuan, perempuan cukup banyak yang ikut berperan dalam kepemimpinan; misalnya Dekan di dua Fakultas, yakni Fakultas Tarbiyah dan Ilmu Keguruan (FTIK) dan Fakultas Dakwah dan Ilmu Komunikasi (FDIK); Wakil Dekan I di FTIK dan FDIK; selain itu ada juga Wakil Dekan II di Fakultas Ekonomi dan Bisnis Islam (FEBI). Selanjutnya juga banyak lagi baik pada tataran Ketua Jurusan maupun Sekretaris atau Kepala Pusat pada Lembaga, serta Sekretaris Jurusan. Kepemimpinan lainnya yang perempuan juga terllibat di dalamnya adalah Kepala Bagian Akademik dan Kemahasiswa, Kasubbag, dan ada juga Kepala Tata Usaha.

Pendapat yang diperoleh dari perhitungan angket terkait dengan kepemimpinan perempuan di IAIN Padangsidimpuan menurut civitas akademika yang berasal dari mahasiswa adalah sejumlahn $65,83 \%$. Kategori skor tersebut berada pada kategori "cukup" yang didapat berdasarkan kategorisasi sebagai berikut:

1) Persepsi yang "baik" diberi skor $76 \%$ sampai dengan $100 \%$.

2) Persepsi yang "cukup" diberi skor $51 \%$ sampai dengan $75 \%$.

3) Persepsi yang "kurang baik" diberi skor $26 \%$ sampai dengan $50 \%$.

4) Persepsi yang "tidak baik" diberi skor $0 \%$ sampai dengan $25 \%$.

Jadi kepemimpinan perempuan dipandang cukup baik dan cukup efektif oleh mahasiswa IAIN Padangsidimpuan.

Berikutnya pandangan civitas akademika lainnya, yakni dosen dan pegawai IAIN Padangsidimpuan tentang kepemimpinan perempuan di IAIN Padangsidimpuan adalah sejumlah 93,93\%. Dari hasil perhitungan tersebut jelas terlihat bahwa kepemimpinan perempuan di IAIN Padangsidimpuan dipandang oleh civitas akademika dari kalangan dosen dan pegawai terlihat dalam kategori "baik". Artinya, civitas akademika "dosen dan pegawai" memandang bahwa pemimpinan perempuan bukanlah suatu halangan untuk menjadikan suatu organisasi menjadi maju. Perempuan dapat menjadi pemimpin yang baik dan bijak, hal itu terbukti dari hasil angket yang telah disebarkan kepada seluruh informan penelitian.

Dari seluruh hasil perhitungan angket keseluruhan maka diketahui pendapat masyarakat IAIN Padangsidimpuan terhadap kepemimpinan perempuan adalah sejumlah 
78,60\%. Dari skor yang didapat di atas dapat dikategorikan persepsi civitas akademika terhadap kepemimpinan perempuan di lingkungan IAIN Padangsidimpuan masuk dalam kategori "baik" yaitu berada antara 76\% sampai dengan 100\%. Kategori skor tersebut didapat berdasarkan kategorisasi sebagai berikut:

1) Persepsi yang "baik" diberi skor $76 \%$ sampai dengan $100 \%$.

2) Persepsi yang "cukup" diberi skor $51 \%$ sampai dengan $75 \%$.

3) Persepsi yang "kurang baik" diberi skor $26 \%$ sampai dengan $50 \%$.

4) Persepsi yang "tidak baik" diberi skor $0 \%$ sampai dengan $25 \%$.

Persentase data angket tentang kepemimpinan perempuan yang diberikan kepada para informan penelitian dapat dilihat pada tabel di bawah ini:

Tabel 1:

Persentase Persepsi Civitas Akademika terhadap Kepemimpinan Perempuan

\begin{tabular}{|c|c|c|c|c|c|c|c|c|c|}
\hline \multirow{2}{*}{$\begin{array}{l}\text { NO. } \\
\text { ANG- } \\
\text { KET }\end{array}$} & \multicolumn{2}{|c|}{ SETUJU } & \multicolumn{2}{|c|}{$\begin{array}{l}\text { TIDAK } \\
\text { SETUJU }\end{array}$} & \multirow{2}{*}{$\begin{array}{l}\text { NO. } \\
\text { ANG- } \\
\text { KET }\end{array}$} & \multicolumn{2}{|c|}{ SETUJU } & \multicolumn{2}{|c|}{$\begin{array}{l}\text { TIDAK } \\
\text { SETUJU }\end{array}$} \\
\hline & $\mathbf{F}$ & $\%$ & $\mathbf{F}$ & $\%$ & & $\mathbf{F}$ & $\%$ & $\mathbf{F}$ & $\%$ \\
\hline 1 & 34 & 38,6 & 53 & 61,4 & 11 & 29 & 32,9 & 56 & 63,6 \\
\hline 2 & 66 & 75 & 21 & 25 & 12 & 31 & 35,2 & 55 & 62,5 \\
\hline 3 & 51 & 57,9 & 36 & 42,1 & 13 & 70 & 79,5 & 14 & 15,9 \\
\hline 4 & 71 & 80,7 & 16 & 19,3 & 14 & 54 & 61,4 & 32 & 36,4 \\
\hline 5 & 44 & 50 & 42 & 47,7 & 15 & 57 & 64,8 & 29 & 32,9 \\
\hline 6 & 55 & 62,5 & 32 & 36,4 & 16 & 66 & 75 & 20 & 22,7 \\
\hline 7 & 37 & 42,04 & 49 & 55,7 & 17 & 29 & 32,9 & 57 & 64,8 \\
\hline 8 & 44 & 50 & 43 & 48,9 & 18 & 30 & 34,1 & 56 & 63,6 \\
\hline 9 & 80 & 90,9 & 6 & 6,8 & 19 & 37 & 42,04 & 49 & 55,7 \\
\hline 10 & 33 & 37,5 & 55 & 62,5 & 20 & 55 & 62,5 & 32 & 36,4 \\
\hline \multicolumn{6}{|c|}{ JUMLAH } & 882 & & 753 & \\
\hline
\end{tabular}

Dari data angket di atas terlihat bahwasanya ada keragaman persepsi tentang kepemimpinan perempuan di IAIN Padangsidimpuan, sesuai dengan penjelasan yang telah diberikan sebelumnya.

Dapat diambil kesimpulan dari data seluruh data yang didapat, baik dari hasil observasi, wawancara, dan angket diketahui bahwa kepemimpinan perempuan telah berjalan dengan cukup efektif, walaupun masih ada pendapat tentang kesenjangan dan kekurangan terhadap kepemimpinan perempuan, namun hal tersebut tentunya sesuai dengan yang dialami di lapangan, dan masih banyak pendapat yang cukup mendukung kepemimpinan perempuan di IAIN Padangsidimpuan. 


\section{ANALISIS}

Kesetaraan gender di IAIN Padangsidimpuan sudah dilaksanakan dengan baik. Dari temuan yang didapat oleh peneliti, bahwasanya masyarakat kampus di lingkungan IAIN Padangsidimpuan sudah cukup memahami tentang kesetaraan gender dan persamaan hak antara laki-laki dan perempuan. jawaban yang diberikan oleh informan penelitian ada juga yang tidak konsisten, karena pada satu pertanyaan tentang bolehkah perempuan memimpin, mereka memberikan jawaban boleh, namun dilain sisi mereka juga menyatakan bahwa laki-laki yang harus menjadi pemimpin. Begitu pula pertanyaan tentang tidak efektifnya kepemimpinan perempuan, jawabannya tidak efektif, namun dilain pertanyaan yang hampir sama mereka menyatakan kepemimpinan oleh perempuan cukup bijaksana.

Sebelum bangsa Barat berbincang tentang kesetaraan gender, sebenarnya Islam sudah lebih dahulu berbicara tentang hal ini. Mengapa demikian? Karena ayat Allah yang menyatakan bahwa perempuan adalah makhluk mulia yang harus dihormati. Al Qur'an secara umum dan dalam banyak ayatnya telah membicarakan relasi gender, hubungan antara laki- laki dan perempuan, hak- hak mereka dalam konsepsi yang rapi, indah dan bersifat adil. Al Qur'an yang diturunkan sebagai petunjuk manusia, tentunya pembicaraannya tidaklah terlalu jauh dengan keadaan dan kondisi lingkungan dan masyarakat pada waktu itu. Seperti apa yang disebutkan di dalam Q.s. Al- Nisa, yang memandang perempuan sebagai makhluk yang mulia dan harus di hormati, yang pada satu waktu masyarakat Arab sangat tidak menghiraukan nasib mereka.

Selanjutnya, sebelum diturunkan surat Al- Nisa ini, telah turun dua surat yang sama sama membicarakan wanita, yaitu surat Al-Mumtahanah dan surat Al-Ahzab. Namun pembahasannya belum final, hingga diturunkan surat al-Nisa' ini ${ }^{27}$. Oleh karenanya, surat ini disebut dengan surat Al-Nisa' al Kubro, sedang surat lain yang membicarakan perempuan juga, seperti surat al -Tholak, disebut surat al-Nisa' al Sughro. Surat Al Nisa' ini benar- benar memperhatikan kaum lemah, yang di wakili oleh anak- anak yatim, orangorang yang lemah akalnya, dan kaum perempuan. Maka, pada ayat pertama surat al-Nisa' kita dapatkan, bahwa Allah telah menyamakan kedudukan laki- laki dan perempuan sebagai hamba dan makhluk Allah, yang masing- masing jika beramal sholeh, pasti akan di beri pahala sesuai dengan amalnya. Kedua-duanya tercipta dari jiwa yang satu (nafsun wahidah), yang mengisyaratkan bahwa tidak ada perbedaan antara keduanya. Semuanya di bawah pengawasan Allah serta mempunyai kewajiban untuk bertaqwa kepada-Nya (ittaqu robbakum).

Kesetaraan yang telah di akui oleh Al Qur'an tersebut, bukan berarti harus sama antara laki- laki dan perempuan dalam segala hal. Untuk menjaga kesimbangan alam (sunnatu tadafu' ), harus ada sesuatu yang berbeda, yang masing-masing mempunyai fungsi dan tugas

\footnotetext{
${ }^{27}$ http://ahmadzain.wordpress.com/2007/03/14/kesetaraan-gender-1/
} 
tersendiri. Tanpa itu, dunia, bahkan alam ini akan berhenti dan hancur. Artinya, apa yang difahami tentang kesetaraan gender selama ini, ternyata telah terlebih dahulu digaungkan oleh Islam; Islam telah menyamakan hak antara perempuan dan laki-laki. Hal ini tentu terkait pula dengan apa yang telah ditemukan pada temuan penelitian di atas, bahwasanya perempuan dan laki-laki memiliki kesamaan hak, namun tetap harus pada fungsi dan tugasnya masing-masing.

Oleh karenanya, sebagai hikmah dari Allah untuk menciptakan dua pasang manusia yang berbeda, bukan hanya pada bentuk dan postur tubuh serta jenis kelaminnya saja, akan tetapi juga pada emosional dan komposisi kimia dalam tubuh. Hal ini akibat membawa efek kepada perbedaan dalam tugas, kewajiban dan hak. Al Qur'an telah meletakkan batas yang jelas dan tegas di dalam masalah ini, salah satunya adalah ayat- ayat yang terdapat di dalam surat al Nisa. ${ }^{28}$

Perempuan posisinya tidaklah lebih rendah dari laki-laki makhluk sejenisnya. Jika ada kelebihan manusia dari makhluk lainnya maka ini adalah kelebihan yang potensial saja sifatnya untuk dipersiapkan bagi tugas dan fungsi kemanusiaan sebagai hamba (sama seperti jin, QS 51:56) dan khalifatullah (khusus manusia QS 2:30). Kelebihan yang disyaratkan sebagai kelebihan pengetahuan (konseptual) menempatkan manusia untuk memiliki kemampuan yang lebih tinggi dari obyek makhluk lain dihadapan Allah. Akan tetapi kelebihan potensial ini bisa saja menjadi tidak berarti ketika tidak digunakan sesuai fungsinya atau bahkan menempatkan manusia lebih rendah dari makhluk yang lain (QS 7:179)29. Hal ini sesuai pula dengan kemampuan dan potensi yang dimiliki oleh kaum perempuan, diantaranya adalah fikiran luas serta kemampuan untuk memimpin. Seperti temuan yang sudah diungkapkan di atas tadi, bahwasanya perempuan juga memiliki kemampuan untuk memimpin, sehingga memperoleh kesempatan untuk menjadi pimpinan, justru dalam tampuk pimpinan tertinggi sekalipun.

Kesetaraan gender tidak harus dipandang sebagai hak dan kewajiban yang sama persis tanpa pertimbangan selanjutnya. Malu rasanya apabila perempuan berteriak mengenai isu kesetaraan gender apabila kita artikan segala sesuatunya harus mutlak sama dengan lakilaki. Karena pada dasarnya, perempuan tentunya tidak akan siap jika harus menanggung beban berat yang biasa ditanggung oleh laki-laki. Atau sebaliknya laki-laki pun tidak akan bisa menyelesaikan semua tugas rutin rumah tangga yang biasa dikerjakan perempuan.

Selanjutnya hasil penelitian ini berkaitan dengan penelitian yang dilakukan oleh Zulfikri ${ }^{30}$ yang menemukan bahwa dalam semangat al-Qur'an tidak ada jenis kelamin yang diistimewakan. Ada keistimewaan perempuan dibalik kelemahannya yang membuat perempuan bisa menjadi perempuan. hal itu juga tercermin dalam hasil penelitian ini

\footnotetext{
${ }^{28} \mathrm{http}$ //ahmadzain.wordpress.com/2007/03/14/kesetaraan-gender-1/

${ }^{29}$ http://derliana.wordpress.com/2010/05/20/gender-menurut-islam/

30 Zulfikri. Konsep Kepemimpinan Perempuan. Laporan Penelitian, tahun 2010. Diakses dari http://digilib.uin-suka.ac.id/5208/ tanggal 20 Mei 2014.
} 
bahwa masyarakat kampus IAIN Padangsidimpuan tidak memandang perbedaan jenis kelamin sebagai kelemahan perempuan, justru kepemimpinan yang dilakukan oleh perempuan terlihat lebih bijaksana, jujur, dan tertata dengan rapi. Berikutnya, terkait dengan penelitian yang dilakukan oleh Sufi Sufiarti ${ }^{31}$ yang menemukan bahwa pemahaman para perempuan tentang gender tidak disertai dengan pemahaman tentang kepemimpinan perempuan, karena sebahagian besar masih terpengaruh dengan budaya dominasi laki-laki. Apa yang menjadi temuan Sufiyarti ini ternyata tidak begitu yang terjadi pada masyarakat IAIN Padangsidimpuan, karena masyarakat IAIN Padangsidimpuan yang memahami tentang konsep gender, cukup memahami kepemimpinan perempuan.

Kesetaraan gender harus dipandang sesuatu yang biasa untuk terjadi dalam hidup bermasyarakat, namun sebagai seorang perempuan juga harus tetap menjaga kodratnya sebagai perempuan, sebagai ibu rumah tangga yang bertanggungjawab terhadap keluarganya. Selain itu, sebagai seorang pimpinan, perempuan juga harus mampu bersifat adil dan bijaksana, serta melakukan kepemimpinan dengan penuh amanah. Atas hal yang terjadi, yang tidak pro terhadap gender, agaknya menjadi perhatian bersama; mungkin ada hal yang perlu menjadi perhatian atau pemikiran sendiri bagi kaum perempuan. Ada hal yang menyebabkan orang tidak peduli akan kesetaraan gender; misalnya ketidakpedulian kaum perempuan dengan anak dan keluarganya, terlalu mementingkan pekerjaan sehingga keluarga terlalaikan, dan lain sebagainya. Selain itu hal yang membuat orang tidak percaya akan kepemimpinan perempuan bisa jadi disebabkan oleh karena kurang amanahnya perempuan dalam menjalankan amanah, atau tidak bertanggungjawab terhadap tugas yang diembankan kepadanya, atau hal lainnya.

\section{PENUTUP}

Kesimpulan

Berdasarkan hasil temuan penelitian maka diketahui bahwa masyarakat kampus IAIN Padangsidimpuan sudah cukup memahami tentang kesetaraan gender. Banyak hal yang dipertanyakan kepada informan, dan informan memberikan respon bahwasanya mereka cukup memahami tentang gender. Masih ada yang kurang memahami tentang gender, namun tetap telah ditemukan bahwasanya civitas akademika cukup memahami tentang gender, sejumlah 75,3\% dengan kategori "cukup".

Selanjutnya, tentang kepemimpian perempuan, kebanyakan informan penelitian menyatakan bahwa perempuan harus dalam melaksanakan kepemimpinannya sudah efektif; namun masih banyak juga yang berpendapat bahwa kepemimpinan perempuan kurang bijaksana. Dari keseluruhan data diketahui bahwa pengetahuan masyarakat IAIN

${ }^{31}$ Sofi Sufiarti. Persepsi Perempuan Berkarir Di Lingkungan UPI Tentang Konsep Kesetaraan Gender. Laporan Penelitian, hlm. 6. 
Padangsidimpuan tentang kepemimpinan sudah cukup baik terbukti dengan kategori skor yang diperoleh yakni 78,6\%.

Temuan penelitian ini menunjukkan bahwa pengarusutamaan gender telah dilaksanakan di IAIN Padangsidimpuan dan kepemimpinan perenmpuan sebagai aplikasi dari kesetaraan gender juga telah terlaksana dengan baik, namun masih perlu untuk ditingkatkan dan dijadikan pertimbangan untuk menjadi lebih baik.

\section{Saran}

Adapun saran yang disampaikan terkait dengan hasil penelitian ini adalah sebagai berikut:

1. Kepada Pimpinan agar lebih memperhatikan dan meningkatkan perhatiannya terhadap kesetaraan gender di IAIN Padangsidimpuan.

2. Kepada para pimpinan perempuan untuk lebih melaksanakan kepemimpinannya dengan baik dan bijaksana, agar orang yang dipimpin tidak merasa bahwa kepemimpinan yang dilaksanakan otoriter, kaku, tidak disiplin, dan memihak atau bahkan terlalu memberikan kelonggaran terhadap orang yang dipimpinnya.

3. Kepada masyarakat kampus baiknya lebih memahami konsep kesetaraan gender, sehingga tidak berimbas kepada keberpihakan terhadap pemimpin laki-laki; selanjutnya juga perlunya rasa saling menghargai demi terlaksananya kepemimpinan yang adil dan bijaksana. 


\section{DAFTAR PUSTAKA}

Alqur'an Digital.

Agenda Pembangunan Nasional diakses dari http://www.bappenas. go.id/files/7113/5230/0985/bab-3-pengembangan-kebudayaan-yang-berlandaskanpada-nilai-nilai-luhur.pdf.

Burhan Bungin, Penelitian Kualitatif Cet. ke- 2 (Jakarta: Kencana Prenada Media Grup, 2008).

Creswell. Research Design: Qualitative, Quantitative, and Mixed Methods Approaches 2nd edition. (London: Sage Publications, 2003.

Direktorat Perguruan Tinggi Agama Islam. Sinopsis dan Indeksasi Hasil Penelitian Kompetitif Dosen PTAIN Tahun 1999 - 2003.(Laporan Penelitian) Imam Suraji, dkk. Peran Kyai dalam Membangun Kesadaran Gender di Kota Pekalongan.

Fahriah Tahar, Pengaruh Diskriminasi Gender dan Pengalaman terhadap Profesionalitas Auditor. Skripsi yang tidak dipublikasikan. Makasar: universitas hasanuddin.

Hasil-hasil Pokok Konsultasi Nasional Agenda Pembangunan Pasca 2015

Ika Rahmawati. Pemahaman Guru dan Siswa tentang Konsep Gender dan Implikasinya dalam Aktifitas Pembelajaran Pendidikan Agama Islam di SMA Muhammadiyah 2 Yogyakarta.

Kasjim Salenda. Kepemimpinan Perempuan Dalam Perspektif Islam. Al-Risalah . Volume 12 Nomor 2 Nopember 2012.

Kartini Kartono. Pemimpin dan Kepemimpinan. Jakarta: Rajawali Press.

Masbow Com, Apa itu Persepsi? Diakses dari http://www.masbow.com/2009/08/apa-itupersepsi.html.

Mansour Fakih. 2003. Analisis Gender \& Transformasi Sosial. Yogyakarta: Pustaka Pelajar.

Martin H. Manser. Oxford Learners' Pocket Dictionary. Oxford University Press.

Miles, M. B. and Huberman, A. M., Qualitative Data Analysis: A Sourcebook of New Method. (New Delhi: SAGE Publications India Pvt. Ltd., 1984)

Musdah Mulia. Kepemimpinan Perempuan di Kampus. Diakses dari www.kalyanamitra. or.id/2014 /02/ kepemimpinan-perempuan-di-kampus/ pada Mei 2014.

Persepsi; Pengertian, definisi, dan faktor yang mempengaruhi. Diakses dari http://www. duniapsikologi.com, 
Robbins, S.P. 2003. Perilaku Organisasi. Jilid I. Jakarta: PT INDEKS Kelompok Garmedia

Sofi Sufiarti. Persepsi Perempuan Berkarir Di Lingkungan UPI Tentang Konsep Kesetaraan Gender. Laporan Penelitian Taha, Zainuddin et.al. 2004. Gender dalam Perspektif Islam dan Budaya Melayu. Makassar: Universitas Negeri Makassar.

Teguh Edhy Wibowo. Gaya Kepemimpinan Perempuan bagi Efektifitas Organisasi. Laporan Penelitian. Universitas Sultan Fatah: Demak.

Zulfikri. Konsep Kepemimpinan Perempuan. Laporan Penelitian, tahun 2010. Diakses dari http://digilib.uin-suka.ac.id/5208/

http://bppkbkajen.blogspot.com/2012/05/arti-dan-istilah-seputaran-pelaksanaan.html. Arti dan Istilah Seputaran Pelaksanaan Pengarusutamaan Gender

http://id.wikipedia.org/wiki/Pengarusutamaan_gender

http://jamilahsay.wordpress.com/2010/11/19/pug-pengarusutamaan-gender-sebagai-strategialternatif-mewujudkan-kesetaraan-gender-dalam-masyarakat/

https://www.academia.edu/3529945/Kepemimpinan__Perempuan_dalam_ Perspektif_AlQuran_Perempuan_sebagai_Pimpinan_Publik

http://www.komnasperempuan.or.id/2013/11/pengarusutamaan-gender-dalam-kebijakanpembangunan/ 